\title{
Aluminum Bioaccumulation in the Earthworm and Acute Toxicity to the Earthworm
}

\author{
ZHAO Li \\ College of Life Sciences and biotechnology \\ Harbin Normal University \\ Harbin, China \\ lili_zhao_cc@126.com
}

\author{
QIU Jiang-ping \\ School of Agriculture and Biology \\ Shanghai Jiao Tong University \\ Shanghai, China \\ jpq@sjtu.edu.cn
}

\begin{abstract}
Aluminum is a highly cytotoxic metal to plants, but its toxicity and accumulation to invertebrates in neutral soils is still unknown. This study is to determine the acute toxicity and bioaccumulation of aluminum to the earthworm. The ecotoxicity tests were based on the methods of international standardization of organization (ISO) and OECD guideline with some modification. The contents of aluminum were measured with Graphite Furnace Atomic Absorption Spectrometry. The experimental period of accumulation test was 32 days. The experiments indicated that aluminum had strongly toxic to earthworms with $\mathrm{LC}_{50}$ of $532.33 \mathrm{mg} \mathrm{Al} / \mathrm{kg}$ dry soil at $\mathrm{pH}$ of 7.0. There were about $1.7 \mathrm{mg}$ monomeric $\mathrm{Al} / \mathrm{kg}$ dry soil and $2.5 \mathrm{mg}$ water-soluble Al/kg dry soil. Earthworms had ability to enrich aluminum at the low contaminated soils doses and bioaccumulation attained maximum then biodegraded obviously. There was a negative correlation evidently between the bioconcentration factor and the dose contaminated soils by Al.
\end{abstract}

Keywords- aluminum; earthworm; bioaccumulation; acute toxicity

\section{INTRODUCTION}

Earthworms were common in vast varies of soils and represented $60 \%$ to $80 \%$ of the total soil biomass [1]. They played an important role in maintaining soil structure and promoting soil ecosystem processes and plant production. Moreover, earthworms can inhabit and survive in soils that were heavily contaminated by metals [2]. Eisenia andrei is one of the most commonly used species in the standard assays of acute and chronic ecotoxicity for industrial chemicals, which make it a key role in terrestrial ecotoxicological risk assessment [3].

Aluminum $(\mathrm{Al})$ is the third most abundant element in the earth's crust. As a major constituent of mineral soils, it is present in the daily life of all organisms and may concentrate and transfer in food chain. But because of its low solubility in a solution under neutral condition, $\mathrm{Al}$ was regarded as a nontoxic element and was often neglected in soil, water, plant and many other samples. Its environmental and biological effects were not investigated until recently. Al was considered to be the most important growth-limiting factor for plants in the soil, even it was a highly cytotoxic metal to plants in acid soils [4]. No data were currently available to confirm that invertebrate could have $\mathrm{Al}$ stress tolerance or resistance, some plant species did, as many genes in plant associated with $\mathrm{Al}$ accumulation [5]. Moreover, bioaccumulation and toxicity of $\mathrm{Al}$ was mainly restricted to plants in acid soils. Little study was known about invertebrate species in neutral soils.

The aim of this study was to determine the acute toxicity and bioaccumulation of $\mathrm{Al}$ to earthworms in the neutral soil. Presently, studies on Al toxicity to animals were mainly on freshwater fish, while few were on soil invertebrate species. Only several studies have determined the effects of $\mathrm{Al}$ on earthworms in acid soil [6, 7]. But Fischer and Rundgren used a highly organic substrate, composed of peat soil mixing with horse manure, which no doubt would have reduced $\mathrm{Al}$ bioavailability and toxicity. Because $\mathrm{Al}$ chemistry is extremely complex and it can form complexes with various organic compounds and inorganic ligands, most but not all of which are soluble [8]. In order to eliminate the effects of variable factors on toxicity, this study was carried out in optimal and stable artificial soils at the laboratory. Moreover, it determined the contents of monomeric and water-soluble $\mathrm{Al}$ which are the phytotoxic Al species.

As metal chloride always used in toxicity test, this study carried out with aluminum chlorin $\left(\mathrm{AlCl}_{3}\right)$.

\section{MATERIALS AND METHOD}

\section{A. Chemicals}

Chemicals of analytical grade and industrial analytical grade quartz sands were supplied by Shanghai chemical reagent company (Shanghai, China).

\section{B. Earthworm treatment}

The Eisenia andrei was purchased from a commercial breeder and kept in the dark at $20 \pm 1{ }^{\circ} \mathrm{C}$ in a mixture of $50 \%$ cow manure for more than 4 weeks. Adults with welldeveloped clitellum were weight from 500 to $600 \mathrm{mg}$. They were voided for $24 \mathrm{~h}$ to clear the gut of debris, then exposed to the filter papers and artificial soils and kept in an artificial climate incubator at temperature $20 \pm 1^{\circ} \mathrm{C}$, humidity $75 \pm 7 \%$, illuminant $1333 \mathrm{~lx}$.

The research was supported by the Science Research Foundation Program of Harbin Normal University, China (No. KM 2007-06). 


\section{Soil preparation}

The compositions of artificial soils were $69 \%$ industrial quartz (0.02 mm--0.5 $\mathrm{mm}$ in diameter), $20 \%$ kaolin clay, $10 \%$ sphagnum peat obtained from an uncontaminated plot. The mixture were dried and crushed. $\mathrm{AlCl}_{3}$ was dissolved into distilled water and added into each replicate of dry soils. The $\mathrm{pH}$ was adjusted to 7.0 with calcium carbonate. Six replicates were set for each dose. The same preparation of soil only without $\mathrm{AlCl}_{3}$ was used as control.

\section{The acute toxicity test}

The acute toxicity test was from the international standard of OECD-guideline No.207 (1984). The total Al concentrations were $347,416,500,600,720,864$, and $1036 \mathrm{mg} \mathrm{Al} / \mathrm{kg}$ dry soil. The death rates and symptoms were recorded respectively after 7th day and 14th day in the artificial soil test.

\section{E. The bioaccumulation test}

The bioaccumulation test was from the international standard of OECD-guideline No.207 (1984). The total Al concentrations were $20,34,50$ and $100 \mathrm{mg} \mathrm{Al} / \mathrm{kg}$ dry soil. The contents of aluminum in the earthworms and the soils were measured with Graphite Furnace Atomic Absorption Spectrometry [9]. The experimental period of accumulation test was 32 days.

\section{F. The determination of monomeric and water-soluble Al in artificial soils}

A spectrophotometry based on the extraction of the 8hydroxyquinoline complex (at $\mathrm{pH}$ 7.2-7.3) into butyl acetate was introduced to determine the monomeric and water-soluble $\mathrm{Al}$ in soil solutions [10]. The separation of very labile $\mathrm{Al}$ species (inorganic aqua, hydroxyl and sulphate Al cationic monomers) by 8-hydroxyquinoline method was based on kinetic strength discrimination, chelating solid phase extraction, and a single extraction procedure with 8hydroxyquinoline [11]. Quantification of $\mathrm{Al}$ concentrations in these extracts can be achieved by fluorometry or UV/visible spectrometry.

\section{G. Statistic analysis}

$\mathrm{LC}_{50}$ of $\mathrm{Al}$ to earthworm was calculated using the Spearman-Karber method [12]. All figures were prepared by EXCEL2000.

\section{RESULTS}

\section{A. The toxicity test}

All earthworms survived in the controls. The mortality rates of earthworms in the treatments were recorded in $7 \mathrm{~d}$ and $14 \mathrm{~d}$ after exposure to the doses of $347,416,500,600,720,864$, and $1036 \mathrm{mg} \mathrm{Al} / \mathrm{kg}$ dry soils (Fig. 1). At the $\mathrm{pH}$ value of 7.0 , the points spread were " $\mathrm{S}$ " curves. The $\mathrm{LC}_{50}$ (with $95 \%$ confidence interval) values for the effect of $\mathrm{Al}$ on earthworm survival were calculated to be 532.33 (490.12-578.07) $\mathrm{mg} \mathrm{Al} / \mathrm{kg}$ dry soils at $14 \mathrm{~d}$ using Spearman-Karber method.
With the increasing of $\mathrm{Al}$ in artificial soils the doses of monomeric and water-soluble $\mathrm{Al}$ in the soils were increasing

(Fig.2). The monomeric $\mathrm{Al}$ doses varied so little that the range was from 1.24 to $2.38 \mathrm{mg} / \mathrm{kg}$ dry soils which the content of the control was $0.93 \mathrm{mg} / \mathrm{kg}$ dry soils. The range of water-soluble was from 1.76 to $9.40 \mathrm{mg} / \mathrm{kg}$ dry soils. The curve of the mortality in artificial soils at $14 \mathrm{~d}$ and the different $\mathrm{Al}$ species was drawn in Fig.3. There were positive correlation evidently between the mortality and the doses of water-soluble Al.

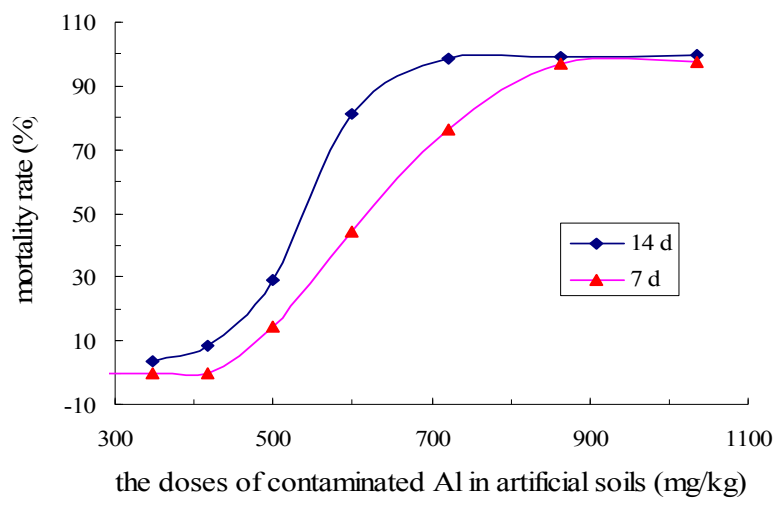

Figure 1. The mortality rate of earthworms in contaminated soils by $\mathrm{Al}$ (Values are means, $n=6$ )



the doses of contaminated $\mathrm{Al}$ in artificial soils $(\mathrm{mg} / \mathrm{kg})$

Figure 2. The curve of $\mathrm{Al}$ species in contaminated soils by Al. (Values are means, $n=3$ ).

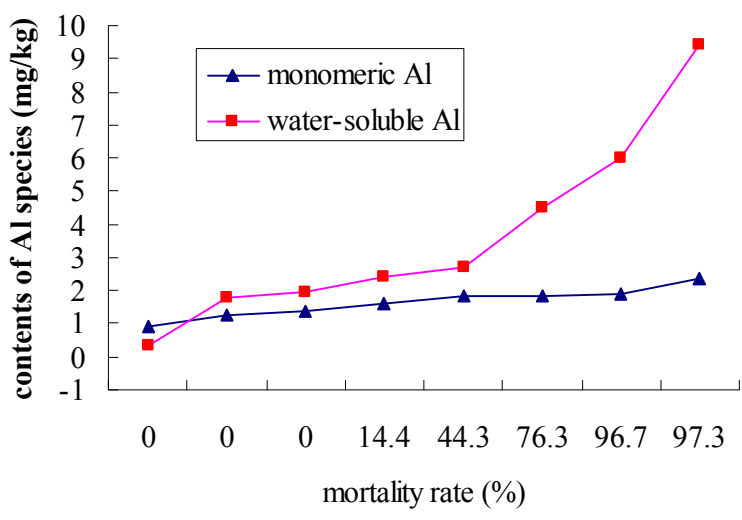


Figure 3. The content curves of $\mathrm{Al}$ in earthworms at different days. (Values are means, $n=6$.)

\section{B. The bioaccumulation test}

All earthworms survived in the test. The contents of aluminum in earthworms fluctuated with test days in Fig.4. The bioaccumulation attained maximum which was about 170 $\mathrm{mg} / \mathrm{kg}$, then descended obviously. It was shown that the contents did not have much direct relation with $\mathrm{Al}$ doses. The bioconcentration factor increased with decreasing of $\mathrm{Al}$ doses (Fig.5). There was a negative correlation evidently between the bioconcentration factor and the dose contaminated soils by Al.

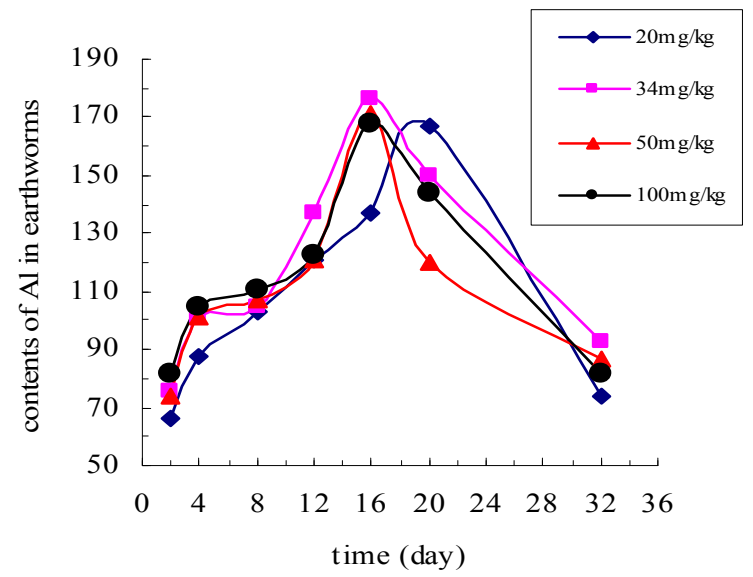

Figure 4. The content curves of $\mathrm{Al}$ in earthworms at different days. (Values are means, $n=6$.)

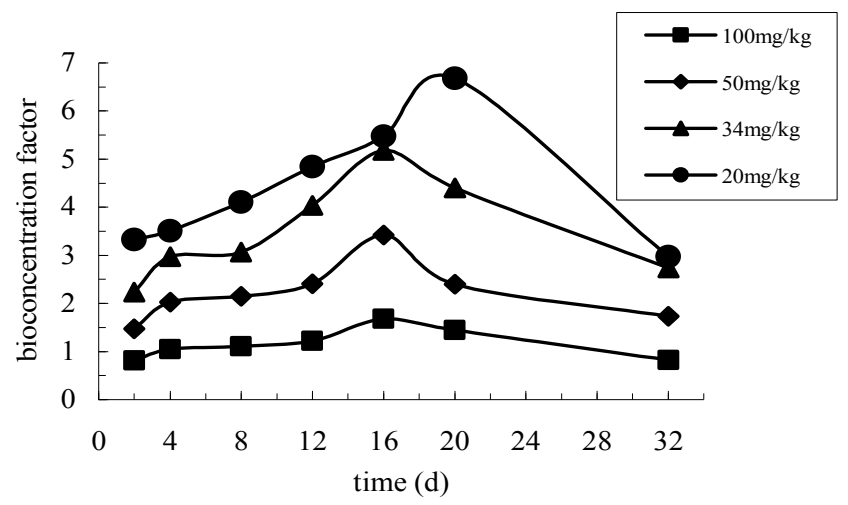

Figure 5. The bioconcentration factor curves of $\mathrm{Al}$ in earthworms at different days. (Values are means, $n=6$ ).

With the increasing of $\mathrm{Al}$ in artificial soils the doses of water-soluble $\mathrm{Al}$ in the soils were increasing (Table.1).

TABLE I. CONTENTS OF WATER-SOLUBLE AL IN ARTIFICIAL SOILS (VALUES ARE MEANS, $\mathrm{N}=3$.)

\begin{tabular}{|c|c|c|c|c|c|}
\hline & \multicolumn{5}{|c|}{ The contents of $\mathrm{Al}\left(\mathrm{mg} \mathrm{Al}^{3+} / \mathrm{kg}_{\mathrm{dry}}\right.$ soil) } \\
\hline Exposed $\mathrm{Al}$ & 0 & 20 & 34 & 50 & 100 \\
\hline $\begin{array}{c}\text { Monomeric } \\
\text { Al }\end{array}$ & $0.45 \pm 0.09$ & $0.59 \pm 0.04$ & $0.79 \pm 0.02$ & $0.83 \pm 0.09$ & $0.87 \pm 0.07$ \\
\hline $\begin{array}{c}\text { Water- } \\
\text { soluble } \boldsymbol{A l}\end{array}$ & $1.39 \pm 0.38$ & $2.07 \pm 0.27$ & $2.27 \pm 0.09$ & $2.67 \pm 0.20$ & $3.17 \pm 0.43$ \\
\hline
\end{tabular}

\section{DISCUSSION}

It is difficult to assess the effects of toxicants since little information on $\mathrm{Al}$ in the soils is currently available. Moreover, as no environmental soil standards of $\mathrm{Al}$ currently, we compared $\mathrm{LC}_{50}$ with those of $\mathrm{CdCl}_{2}$ and $\mathrm{CuCl}_{2}$, and use environmental quality standard for soils of China (1995) and soil contamination countermeasures law in Japan (1992) as the basis for a more thorough assessment. All data were shown in Table 2. The $\mathrm{LC}_{50}$ values of $\mathrm{Cd}, \mathrm{Cu}$ and $\mathrm{Al}$ were $875.06 \mathrm{mg} / \mathrm{kg}$, $116.91 \mathrm{mg} / \mathrm{kg}$, and $532.33 \mathrm{mg} / \mathrm{kg}$ respectively, so it was clearly indicated that the acute toxicity of $\mathrm{Al}$ to earthworms was stronger than $\mathrm{Cd}$ but weaker than $\mathrm{Cu}$. There were precise prescripts for $\mathrm{Cd}$ and $\mathrm{Cu}$ of soil laws in China and Japan. Therefore, considering its acute toxicity, $\mathrm{Al}$ should be of highly concern.

TABLE II. ENVIRONMENTAL QUALITY STANDARD FOR SOILS OF CHINA, JAPAN AND THE RESULTS OF THIS TEST

\begin{tabular}{|c|c|c|c|c|c|}
\hline \multirow{4}{*}{ metal } & \multicolumn{4}{|c|}{$\begin{array}{l}\text { Environmental quality standard for soils } \\
\text { (mg/kg) }\end{array}$} & \multirow{3}{*}{$\begin{array}{c}\text { This study } \\
\text { (mg/kg) } \\
\text { Artificial } \\
\text { soil } \\
\text { LC }_{50}\end{array}$} \\
\hline & \multicolumn{3}{|c|}{ China (GB 15618-1995) } & \multirow{3}{*}{$\begin{array}{c}\text { Japan } \\
\text { (JIS } \\
46- \\
1992)\end{array}$} & \\
\hline & \multicolumn{2}{|c|}{ Dipole } & Tertiary & & \\
\hline & $p H>7.5$ & pH 6.5-7.5 & $p H>6.5$ & & $p H 7.0$ \\
\hline$C d$ & $\leq 0.60$ & $\leq 0.30$ & $\leq 1.0$ & $\leq 1.0$ & $L C_{50} 875.05$ \\
\hline Cu(cropland) & $\leq 100$ & $\leq 100$ & $\leq 400$ & $\leq 125$ & $L C_{50} 116.91$ \\
\hline$A l$ & none & none & none & none & $L C_{50} 532.33$ \\
\hline
\end{tabular}

Earthworms could accumulate $\mathrm{Cd}$ and $\mathrm{Cu}$ rapidly and transform to non-toxic form [13, 14]. In this bioaccumulation test it indicated that earthworms had ability to enrich aluminum at the low contaminated soils doses, but after the contents of $\mathrm{Al}$ attained maximum it was not to stay the same. It then descended obviously. The bioconcentration factor increased with decreasing of $\mathrm{Al}$ doses. It was difficult to interpret mechanism of toxicity and detoxification. The earthworm absorbed and digested $\mathrm{Al}$ through alimentary canal, this process was so slow that tolerance or resistance to the metal pressures might evolve.

The other reason may be attributed to the different $\mathrm{pH}$ values. It is generally assumed that aluminum toxicity is caused by labile monomeric aluminum species. When the $\mathrm{pH}$ of a solution is raised above $4.0, \mathrm{Al}^{3+}$ forms the monomeric species $\mathrm{AlOH}^{2+}, \mathrm{Al}(\mathrm{OH})_{3}{ }^{+}, \mathrm{Al}(\mathrm{OH})_{3}, \mathrm{Al}(\mathrm{OH})_{4}^{-}$and $\mathrm{Al}^{3+}$ undergoes repeated deprotonations to form insoluble $\mathrm{Al}(\mathrm{OH})_{3}$ at $\mathrm{pH} 7.0$ [15]. Al occurs in the various chemical species, of which the monomeric and water-soluble species were found to be the most crucial to evaluate its toxicity in the soils [16]. There were positive correlation evidently between the mortality and doses of monomeric and water-soluble $\mathrm{Al}$ species in the acute toxicity test. Furthermore, the OECD standard artificial soil contains $20 \%$ kaolin clay, which had a purity of approximately $50 \%$. Considering that kaolin $\left(\mathrm{Al}_{4}\left(\mathrm{Si}_{4} \mathrm{O}_{10}\right)(\mathrm{OH})_{8}\right)$ on a mass basis contains $20.9 \% \mathrm{Al}$, it could be concluded that artificial 
soil with $10 \%$ pure kaolin clay contains approximately $2 \% \mathrm{Al}$. Whereas it was generally considered that the speciation of $\mathrm{Al}_{4}\left(\mathrm{Si}_{4} \mathrm{O}_{10}\right)(\mathrm{OH})_{8}$ was innocuous and stable so that it is commonly used in artificial soil test. And the quantity of calcium carbonate added could lead to different results. Al toxicity could be counteracted by calcium, species of low calcium exhibited higher tissue metal concentrations compared with species of high calcium [17]. But that is not the major factor of toxicity. The behavior and physiology of earthworms could change physical properties of soil, which unfortunately affected the chemical's fate and bioavailability.

\section{CONCLUSION}

In the neutral soils, $\mathrm{Al}$ acute toxicity to earthworm falls between $\mathrm{Cu}$ and $\mathrm{Cd}$. Therefore, $\mathrm{Al}$ toxicity must be a concern, particularly when $\mathrm{Al}$ has an adverse effect on ecosystem that may concentrate and transfer within the food chain, which subsequently affects animals of higher grade along the food chain. Moreover, Al has direct toxicity to earthworms, an interaction occurs that causes a twofold change in sensitivity (for juvenile production), while there is no apparent effect of conditions on the pattern of physiological responses.

Earthworms had ability to accumulate aluminum at the low contaminated soils doses and the contents of bioaccumulation attained maximum then biodegraded obviously. There was a negative correlation evidently between the bioconcentration factor and the dose contaminated soils by Al. The cause could be cytological and histological factors which need to interpret in further research.

\section{ACKNOWLEDGMENT}

The research was supported by the Science Research Foundation Program of Harbin Normal University, China (No. KM 2007-06).

\section{REFERENCES}

[1] A. Bouché, "Earthworm species and ecotoxicological studies. In: GreigSmith, P.W., Becker, H., Edwards, P.J., Heimbach, F. (Eds.),” Intercept, Andover, UK, pp. 20-35, 1992.

[2] T. Lukkari., M. Taavitsainen, M. Soimasuo, A. Oikari, and J. Haimi, "Biomarker responses of the earthworm Aporrectodea tuberculata to copper and zinc exposure: differences between populations with and without earlier metal exposure," Environmental Pollution, vol. 129, pp. 377-386, 2004.
[3] J. M. Weeks, S. D. W. Comber, "Ecological risk assessment of contaminated soil," Mineralogical Magazine, vol. 69, pp. 601-613, 2005.

[4] P. Pejchar, R. Pleskot, K. Schwarzerová, J. Martinec, O. Valentocá and Z. Novotná, "Aluminum ions inhibit phospholipase D in a microtubuledependent manner," Cell Biology International, vol. 32, pp. 554-556, 2008..

[5] D. Chandran, N. Sharopova, S. Ivashuta, J. S. Gantt, K. A. VandenBosch and D. A. Samac, "Transcriptome profiling identified novel genes associated with aluminum toxicity, resistance and tolerance in Medicago truncatula," Planta, vol. 228, pp. 151-166, 2008..

[6] E. Fischer and L. Molnár, "Growth and reproduction of Eisenia fetida (Oligochaeta, Lumbricidae) in semi-natural soil containing various metal chlorides.," Soil Biology and Biochemistry vol. 29, pp. 667-670, 1997...

[7] S. Rundgren and P. Nilsson, "Sublethal effects of aluminium on earthworms in acid soil: the usefulness of Dendrodrilus rubidus (Sav.) in a laboratory test system," Pedobiologia, vol. 41, pp. 417-436, 1997...

[8] CCME, “"Canadian drinking quality guidelines. Canadian Council of 14 Minister of the Environment," Ottawa, Ontario, 1988.

[9] J. P. Qiu, L. Zhao and L. A. Lin, " Determination of aluminum in earthworms by graphite furnance atomic absorption spectrometry," Chinese Journal of Analydid Laboratory, vol. 24. suppl, pp. 111-113, 2005.

[10] J. Y. Li, R. K. Xu and G. L. Ji, "Determination of soluble Al in acid soil solution using spectrophotometry with 8-hydroxyquinoline at $\mathrm{pH}$ 8.3.," Soils, vol. .36, pp. 307-309, 2004.

[11] P. Matúš, "Evaluation of separation and determination of phytoavailable and phytotoxic aluminum species fractions in soil, sediment and water samples by five different methods," Biochemistry, vol. 101, pp. 12141220, 2007.

[12] H. A. Hamilton, R. C. Russo and R. V. Thurston, “ Trimmed SpearmanKarber method for estimating median lethal concentrations in toxicity bioassays," Environmental Science and Technology, vol. 11, pp. 714719., 1977/1978.

[13] R. E. Arnold, M. .E. Hodson and C. J. Langdon, "A $\mathrm{Cu}$ tolerant population of the earthworm Dendrorilus rubidus (Savigny, 1862) at coniston copper mines," cumbria UK. Environmental pollution vol. 152, pp. 713-722, 2008.

[14] T. N. Thanh, R. S. Stephen and J. S. Martin, "Cadmium binding studies to the earthworm Lumbricusrubellusmetallothionein by electrospray mass spectrometryand circular dichroism spectroscopy," Biochemical and Biophysical Research Communications vol. 351, pp. 229-233, 2006.

[15] K. P. Sanjib and M. Hideaki, “ Molecular physiology of aluminum toxicity and tolerance in plants," The Botanical Review, vol. 73(4), pp. 326-347, 2007.

[16] M. Peter, K. Jana B. Marek and M. J'an, "Free aluminium extraction from various reference materials and acid soils with relation to plant availability.," Talanta, vol. 70, pp. 96-105, 2006.

[17] C. N. Lowe and K. R. Butt, "Earthworm culture, maintenance and species selection in chronic ecotoxicological studies: A critical review," European Journal of Soil Biology, vol. 43, pp. 281-288, 2007. 